\title{
A study to observe quantitative levels of C- Reactive Protein in Cerebrospinal fluid in patients with Meningitis as an add-on routine investigation- a case-control study
}

\author{
Kumar M. ${ }^{1}$, Tiwari C. ${ }^{2 *}$, Prabhat N. ${ }^{3}$, Dhaon P. ${ }^{4}$, Uraiya D. ${ }^{\mathbf{5}}$ \\ DOI: https://doi.org/10.17511/ijmrr.2021.i04.05
}

\footnotetext{
1 Manoj Kumar, M.D., Assistant Professor, Department of Medicine, Hind Institute of Medical Sciences, Barabanki, Uttar Pradesh, India.

2* Chandra Shekhar Tiwari, M.D., Assistant Professor, Department of Medicine, Hind Institute of Medical Sciences, Barabanki, Uttar Pradesh, India.

3 Nandita Prabhat, D.M., (Neurology), Assistant Professor, Department of Medicine, Hind Institute of Medical Sciences, Barabanki, Uttar Pradesh, India.

${ }^{4}$ Pooja Dhaon, M.D., Associate Professor, Department of Medicine, Hind Institute of Medical Sciences, Barabanki, Uttar Pradesh, India.

5 Dharmendra Uraiya, M.D., Professor, Department of Medicine, Hind Institute of Medical Sciences, Barabanki, Uttar Pradesh, India.
}

Introduction: C-reactive protein (CRP) is a member of the class of acute phase reactants as its level rises dramatically during inflammatory processes occurring in the body. Measuring and charting CRP values can prove useful in determining the disease progress. Aim: To estimate the CRP level in Cerebrospinal fluid (CSF) of patients with meningitis; and to evaluate whether CRP levels could be used to differentiate the various types of meningitis in adults. Materials and Methods: This study was a case-control study. 80 enrolled patients were subjected to a protocol that included detailed clinical history including duration of illness, symptoms and signs, history or any treatment history. Written informed consent was taken from the patients/guardian. Results: Meningitis was more common in the 18-30 years age group. Mean values of CSF CRP were- viral meningitis $(2.70 \mathrm{mg} / \mathrm{L}$ ) and pyogenic meningitis $(91.13 \mathrm{mg} / \mathrm{L})$ and control group $(1.54 \mathrm{mg} / \mathrm{L})$. CSF CRP can be used as a diagnostic tool to differentiate between pyogenic and viral meningitis as it is significantly raised in pyogenic meningitis in comparison to viral meningitis ( $p$-value <0.0001). Conclusion: CRP in CSF is a valuable, rapid, bedside diagnostic test for differentiating between pyogenic and viral meningitis; with reasonably good sensitivity, specificity and positive predictive value. The absence of CRP in CSF rather than its presence is more important for the diagnosis of viral meningitis.

Keywords: Cerebrospinal fluid, C-reactive protein, Meningitis

Corresponding Author

Chandra Shekhar Tiwari, M.D., Assistant Professor, Department of Medicine, Hind Institute of Medical Sciences, Barabanki, Uttar Pradesh, India. Email: chandrashekhartiwari64@gmail.com
How to Cite this Article To Browse

Kumar M, Tiwari CS, Prabhat N, Dhaon P, Uraiya D. A study to observe quantitative levels of C- Reactive Protein in Cerebrospinal fluid in patients with Meningitis as an add-on routine investigation- a case-control study. Int J Med Res Rev. 2021;9(4):235-240. Available From https://ijmrr.medresearch.in/index.php/ijmrr/article/ view/1299

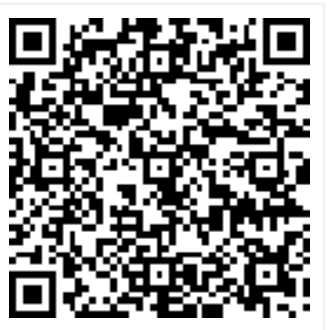

Review Round 3
2021-07-27
Plagiarism X-checker
$8 \%$

$8 \%$
Accepted 2021-07-29 2021-07-04 Nil
Ethical Approval Yes (C) 2021 by Manoj Kumar, Chandra Shekhar Tiwari, Nandita Prabhat, Pooja Dhaon, Dharmendra Uraiya and Published by
Siddharth Health Research and Social Welfare Society. This is an Open Access article licensed under a Creative Commons Attribution 4.0 International License https://creativecommons.org/licenses/by/4.0/ unported [CC BY 4.0] 


\section{Introduction}

The cerebrospinal fluid (CSF) is a clear, colourless, plasma-like fluid that circulates in the brain ventricles and the cranial and spinal subarachnoid spaces. The mean CSF volume is around $150 \mathrm{ml}$ and it is renewed about four times every 24 hours. Reduction of the CSF turnover rate during ageing leads to the accumulation of catabolites in the brain and CSF that are also observed in certain neurodegenerative diseases $[1,2]$. The CSF space is a dynamic pressure system. CSF pressure determines intracranial pressure with physiological values ranging between 3 to $4 \mathrm{mmHg}$ before the age of one year, and between 10 and $15 \mathrm{mmHg}$ in adults. Apart from its function of hydromechanical protection of the central nervous system, CSF also plays a prominent role in brain development and regulation of brain interstitial fluid homeostasis, which influences neuronal functioning [3]. Meningitis is an inflammation of the meninges (the membranes surrounding the brain and spinal cord) and the cerebrospinal fluid (CSF) in the arachnoid space. It is most often caused by a tubercular, bacterial or viral infection. Bacterial meningitis remains a serious threat to global health accounting for an estimated annual 1,70,000 deaths worldwide. Three species, H. influenza, Streptococcus pneumoniae and $\mathrm{N}$. meningitides, are responsible for most cases of bacterial meningitis [2-5]. Creactive protein (CRP) is the prototype acute phase protein since its discovery approximately 80 years ago. It is a normal serum constituent present in healthy individuals in very low concentrations $(<5$ $\mathrm{mg} / \mathrm{L}$ ). Invasive bacterial infection and extensive tissue damage cause an increase in CRP levels. CRP is the fastest rising acute phase reactant and normalizes rapidly following successful therapy or removal of the stimulus [5]. Measurement of CRP concentration provides valuable information for the diagnosis of bacterial meningitis, septicemia and pneumonia. CRP levels are sometimes used as a rapid test for presumptive diagnosis of a bacterial infection versus viral infection. CRP is often used by a rheumatologist to monitor the progression or remission of autoimmune disease $[6,7]$.

Due to overlap in clinical features and CSF findings in various types of meningitis, sometimes it becomes difficult to differentiate bacterial meningitis from other meningitis in resource-limited settings. In such circumstances the estimation of CSF CRP concentration provides a new dimension to the specific diagnosis of meningitis.
CRP is a member of the class of acute phase reactants as its level rises dramatically during inflammatory processes occurring in the body. Measuring and charting CRP values can prove useful in determining disease progress. By this study we tried to establish the credibility of CSF- CRP measurements in differentiating bacterial meningitis from viral meningitis.

\section{Material and Methods}

This is a case-control study conducted in the Department of Medicine at Hind Institute of Medical Sciences, Barabanki from October 2019 to March 2020. Eighty patients were enrolled in the study. Random sampling was done. Population size was 100 with a confidence level of $95 \%$ and a margin of error of $5 \%$ with this the sample size was 80 . All patients with age $>18$ years and clinical features suggestive of meningitis were included in the study. The exclusion criteria included patients with age < 18 years, acute infections at sites other than the central nervous system, patients in whom lumbar puncture was contraindicated, patients on steroid, Hormone replacement therapy, pregnancy and lactation, diabetes mellitus, evidence of hepatic disease or cirrhosis and inflammatory conditions e.g. Arthritis, SLE. The Control group consisted of 20 age and sex-matched individuals whose clinical diagnosis was other than meningitis such as patients with acute respiratory tract infection, with meningismus, acute flaccid paralysis and febrile convulsions.

The enrolled patients were subjected to a predefined protocol which included detailed clinical history regarding the duration of illness, symptoms and signs, history or any treatment history. The selected cases were subjected to the following investigations - Intracranial pressure measurement; CSF examination including cell counts, Sugar, Protein, Chloride, ADA and CRP. Data was collected by a pretested semi-structured questionnaire, clinical examination and investigations. We did not use any scoring system. An estimation of CSF Creactive protein level was done for all the patients satisfying the inclusion and exclusion criteria and also for all controls. Specifics for collection and panels were CSF in 3 sterile test tubes, 2-4 ml each; Tube 1 for cellular, biochemical and direct smear examination; Tube 2 for CRP latex agglutination and Tube 3 for CSF culture. It was processed within 1 hour of collection or stored and processed within 24 hours. 
CRP level was estimated by liquid phase immune precipitation assay with nephelometric endpoint detection. Fresh undiluted CSF was used. Turbid samples were centrifuged before assay. The normal value was taken below $6 \mathrm{mg} / \mathrm{L}$. The study was approved by Institutional Ethical Committee and written informed consent was obtained from each patient/guardian and controls. Statistical analysis was done by SPSS version 12.0 for Window. Observations were tested statistically by the Chisquare and the Student t-test was used for sensitivity, specificity and positive predictive value of CSF CRP in different types of meningitis. For the significance of the test Pearson chi-square test was done. A p-value of $<0.05$ was considered statistically significant.

\section{Results}

The present study was conducted on 80 patients with meningitis admitted in the Medicine ward of Hind Institute of Medical Sciences, Safedabad. Twenty age and sex-matched individuals in which clinical diagnosis was other than meningitis were taken as the control group. 64 subjects were present in Study Group A (Viral Meningitis). The maximum number of subjects were in the age group $18-30$ yrs with 32 patients (50\%) being males and $32(50 \%)$ were females. The mean age of patients in Group A was 26.38 yrs. Group B (Pyogenic Meningitis) included 16 subjects. The mean age of this study group was 22.38 yrs, 12(75\%) were males and $4(25 \%)$ were females. A maximum number of the subjects were in the age group 18-30 yrs. Among the 20 subjects in the control group, $11(55 \%)$ were male and $9(45 \%)$ were female. The mean age was 28.95 years. (Table 1 ).

Table 1: Sex Distribution of Study Group

\begin{tabular}{|l|l|l|l|l|l|l|}
\hline \multirow{2}{*}{ Group } & \multicolumn{2}{|c|}{ Male } & \multicolumn{2}{c|}{ Female } & \multicolumn{2}{c|}{ Total } \\
\cline { 2 - 7 } & No. & $\%$ & No. & $\%$ & No. & $\%$ \\
\hline A (Viral Meningitis) & 32 & 50 & 32 & 50 & 64 & 100 \\
\hline B (Pyogenic Meningitis) & 12 & 75 & 4 & 25 & 16 & 100 \\
\hline Total & 44 & 55 & 36 & 45 & 80 & 100 \\
\hline
\end{tabular}

It was observed that out of these 80 cases, males $44(55 \%)$ outnumbered the females $36(45 \%)$ as shown in table 1
Table 2: CSF C-reactive protein in study group \& control group

\begin{tabular}{|l|l|l|l|}
\hline \multicolumn{1}{|c|}{ Group } & N & \multicolumn{1}{|c|}{ Mean(mg/L) } & \multicolumn{1}{c|}{ SD } \\
\hline A (Viral Meningitis) & 64 & 2.70 & 1.55 \\
\hline B (Pyogenic Meningitis) & 16 & 91.13 & 11.21 \\
\hline Control & 20 & 1.54 & 0.59 \\
\hline
\end{tabular}

Table 2 shows average CSF CRP values in the study groups and control groups. Mean CRP in patients with viral meningitis is $2.70 \mathrm{mg} / \mathrm{L}$, Pyogenic meningitis is $91.13 \mathrm{mg} / \mathrm{L}$; while that in the control group is $1.54 \mathrm{mg} / \mathrm{L}$. The mean value of CSF CRP in the patients with pyogenic meningitis is statistically significantly raised as compared to viral meningitis ( $p$ value $<0.0001$ )

Table 3: Comparison of CSF CRP in group A and B

\begin{tabular}{|l|l|l|c|c|c|}
\hline \multicolumn{1}{|c|}{ Group } & No. & Mean(mg/L) & SD & t-value & p-value \\
\hline A (Viral Meningitis) & 64 & 2.70 & 1.55 & 44.607 & $<0.0001$ \\
\cline { 1 - 4 } B (Pyogenic Meningitis) & 16 & 91.13 & 11.21 & & \\
\hline
\end{tabular}

The mean value of CSF CRP in the cases of the pyogenic group is $91.13 \mathrm{mg} / \mathrm{L}$ which is statistically significantly raised than that in the viral group (mean value $2.70 \mathrm{mg} / \mathrm{L}$ ) ( $\mathrm{p}$ value<0.0001).

Table 4: Comparison of CSF CRP in group A and control

\begin{tabular}{|l|l|l|r|l|l|}
\hline \multicolumn{1}{|c|}{ Group } & No. & Mean $(\mathrm{mg} / \mathrm{L})$ & SD & t-value & p-value \\
\cline { 1 - 5 } A (Viral Meningitis) & 64 & 2.70 & 1.55 & 3.182 & $<0.002$ \\
\cline { 1 - 3 } & 20 & 1.54 & 0.59 & & \\
\hline
\end{tabular}

The table compares CSF CRP in the viral group and control group. The mean value of CSF CRP in the viral group is $2.70 \mathrm{mg} / \mathrm{L}$ while that in the control group is $1.54 \mathrm{mg} / \mathrm{L}$ which is statistically significant (p-value $<0.002$ ).

Table 5: Comparison of CSF CRP in group B and control

\begin{tabular}{|l|l|l|c|l|l|}
\hline \multicolumn{1}{|c|}{ Group } & No. & Mean(mg/L) & SD & t-value & P-value \\
\cline { 1 - 4 } B(Pyogenic Meningitis) & 16 & 91.13 & 11.218 & 36.65 & $<0.0001$ \\
\hline Control & 20 & 1.54 & 0.595 & & \\
\hline
\end{tabular}

The mean value of CSF CRP in the pyogenic group is $91.13 \mathrm{mg} / \mathrm{L}$ which was statistically significantly raised than that in the control group $1.54 \mathrm{mg} / \mathrm{L}$ ( $p$ value<0.0001).

Table 6: Diagnostic utility of CRP test in CSF

\begin{tabular}{|l|l|l|l|l|l|l|}
\hline \multicolumn{1}{|c|}{ Meningitis } & No. & \multicolumn{1}{c|}{ CRP +ve } & \multicolumn{1}{c|}{ CRP -ve } & \multicolumn{1}{c|}{ Sensitivity } & \multicolumn{1}{c|}{ Specificity } & \multicolumn{1}{c|}{ Positive predictive value } \\
\hline Pyogenic & 16 & 16 & 0 & $100 \%$ & $100 \%$ & $100 \%$ \\
\hline Viral & 64 & 4 & 60 & $6.25 \%$ & $100 \%$ & $100 \%$ \\
\hline Control & 20 & - & 20 & - & - & - \\
\hline
\end{tabular}




\begin{tabular}{|l|l|l|l|l|l|l|}
\hline Total & 100 & 20 & 80 & - & - & - \\
\hline
\end{tabular}

The table shows estimates of CRP in CSF for pyogenic meningitis with $100 \%$ sensitivity, specificity and positive predictive value. The absence of CRP rather than its presence is more important for the diagnosis of viral meningitis.

\section{Discussion}

Meningitis is a major health problem all over the world, especially in developing countries like India. Early and reliable etiological diagnosis is the key to a successful outcome. The etiological diagnosis of meningitis in developing countries remains a problem in clinical practice as CSF biochemical analysis and cellular response often overlap. This becomes even more difficult in a population like India where tuberculous meningitis is more prevalent. The rapid diagnostic tests including counter immunoelectrophoresis and enzyme-linked immune sorbent assay (ELISA) help establish the diagnosis but these tests are costly, difficult to perform and not easily available. In such circumstances, the estimation of CRP concentration in the CSF provides a new dimension to the specific diagnosis of meningitis. Peltola, H.O (1982) and Debeer, F.C., Kirsten et al (1984) used serum CRP levels to monitor the infections of the central nervous system and also to differentiate between pyogenic and viral meningitis, since the CRP levels are significantly lower in cases of viral meningitis.

The mechanism by which CRP gains access to CSF is still not known, however, passive diffusion across the highly inflamed meninges would be a reasonable explanation [8]. S, Tiamkao S et al (2005) measured the serum and CRP levels in patients who were diagnosed clinically as bacterial and aseptic meningitis. The mean and serum CRP level in bacterial meningitis and aseptic meningitis group was $209.25 \pm 105.23$ and $67.05 \pm 40.81$ respectively ( $p$ value $<0.001$ ) [9]. In a study conducted by Vaishnavi $C$ et al (1992) CRP in CSF was significantly higher in patients with pyogenic meningitis compared to TBM. The authors concluded that the estimation of CRP in patients with suspected meningitis might be made to give a preliminary diagnosis of pyogenic meningitis [10]. The study by Hemavani $V$ et al (2001) concluded that CSF CRP determination can be of value to differentiate pyogenic versus other microbial meningitis etiology.
However, it cannot differentiate between tuberculous, fungal and viral meningitis [11]. A meta-analysis by Gerdes LU et al (1998) suggested that a negative CRP test in either CSF or serum can be used with a very high probability to rule out bacterial meningitis. The present study was conducted to evaluate the role of CSF CRP in the differentiation of pyogenic meningitis and viral meningitis. CSF-CRP values appeared to be more sensitive in differentiating bacterial and nonbacterial meningitis than the usual parameters measured in CSF like cell count, protein, sugar and gram stain. To conclude, estimation of CRP in CSF can be used as a simple bedside diagnostic tool to differentiate between bacterial and viral meningitis [12]. Hansson I O and Axelsson et al (1993): The ability of serum C- reactive protein to differentiate between acute bacterial and viral meningitis was evaluated in 235 patients. Serum CRP value above $50 \mathrm{mg} / \mathrm{l}$ in patients with CSF pleocytosis usually indicates bacterial etiology.

However, S-CRP values above $50 \mathrm{mg} / \mathrm{l}$ may occasionally be seen in viral meningitis [13]. Prasad, PL et al (2005): At Armed Forces Medical College there were 63 cases of meningitis admitted in the hospital. By gold standard, there were 38 cases of bacterial, 21 cases of tubercular and 4 cases of viral meningitis. $H$. influenza was the predominant organism grown. CSF C-reactive protein was raised in 33 cases of bacterial and 2 cases of tubercular meningitis. Serum C-reactive protein was raised in 29 cases of bacterial, and eight cases of tubercular meningitis. These tests were negative in all cases of viral meningitis. The sensitivity and specificity of serum and CSF C-reactive protein was $96 \%$ and $100 \%$ [14]. In the Indian subcontinent Vaidya et al(1987) had studied 150 cases of latex agglutination and suggested CRP detected by latex agglutination is a helpful screening test to differentiate bacterial and non-bacterial meningitis at the bedside and CRP detected patients should be considered to have bacterial meningitis until proved otherwise. Out of these, 20 were controls in which CRP was negative. Protein, sugar, chlorides and cell count were normal. Bacteriologically, these samples were sterile. Out of 130 clinically suspected cases of meningitis, 100 cases were proved by positive culture as pyogenic meningitis. Cell count in these cases showed predominant polymorphs, increased protein level and low sugar. 
Twenty-six cases were proved either by direct or indirect evidence as tuberculous meningitis. In all these cases, CSF-CRP was positive. The remaining 4 cases were bacteriologically sterile. In these 4 cases, CSF cell count was 100-200 cells, the polymorph-lymphocyte ratio was overlapping, the protein was marginally increased and sugar was normal. All these cases were clinically diagnosed as viral meningitis. CSF-CRP was negative. Three cases were followed up, and repeat CSF showed a decrease in cell number and CRP was again negative [15]. Sutinen J, Sombrero L et al (1998/1999): Among 103 patients with CNS infection, etiology was identified in 60 (58\%) cases. Bacteria were found in 19 (including 7 Streptococcus pneumoniae, 5 Haemophilus influenzae, 3 Neisseria meningitidis), tuberculosis in 4, viruses in 38 (including 20 coxsackievirus, 8 measles, 4 adenovirus, and 4 poliovirus infections), and brain abscess in 3 patients. C-reactive protein was elevated on admission in all 18 cases of bacterial meningitis tested, exceeding $50 \mathrm{mg} / \mathrm{L}$ in 17 (94\%), and was not affected by prior antibacterial treatment. The mean CRP was significantly higher in the bacterial group than in the viral group $(207+/-111 \mathrm{mg} / \mathrm{L}$ vs. $39+/-34 \mathrm{mg} / \mathrm{L} ; \mathrm{P}<0.001)$. In the viral group one third had CRP above $50 \mathrm{mg} / \mathrm{L}$. In patients with tuberculous meningitis, brain abscess, or cryptococcal meningitis, CRP was moderate to highly elevated [16].

\section{Conclusion}

Meningitis because of its acute morbidity and long term risk of brain damage, learning disabilities, mental retardation, hearing loss or death, differentiation between pyogenic meningitis and viral meningitis is extremely important because of their therapeutic and prognostic significance. To date there are various tests available that help establish the etiological diagnosis but every test has some drawbacks. The rapid diagnostic tests including counter immunoelectrophoresis and enzyme-linked immunosorbent assay (ELISA), help establish an etiologic diagnosis, but these tests are costly, difficult to perform and not easily available. If the patient has received inadequate antibiotics and ATT, the CSF often becomes sterile. Biochemistry may be altered and pleocytosis persists though the nature of the cells changes. It poses a difficult problem in the differential diagnosis from bacterial and viral meningitis. In such circumstances the estimation of CSF CRP concentration provides a new dimension to the specific diagnosis of meningitis.
CRP is the fastest rising acute phase reactant and is secreted in increased amounts within 6 hours of an acute inflammatory stimulus. CSF CRP can be used as a diagnostic tool to differentiate between pyogenic and viral meningitis. This study establishes the credibility of CRP as a diagnostic tool in differentiation between pyogenic and viral meningitis. Though the present sample size is very small to draw any result, the following conclusion can be made from this study:- Meningitis is more common in the 18-30 years age group; mean values of CSF CRP are- viral meningitis (2.70 $\mathrm{mg} / \mathrm{L})$ and pyogenic meningitis ( $91.13 \mathrm{mg} / \mathrm{L})$ and control group $(1.54 \mathrm{mg} / \mathrm{L})$.

CSF CRP can be used as a diagnostic tool to differentiate between pyogenic and viral meningitis as it is significantly raised in pyogenic meningitis in comparison to viral meningitis ( $p$-value $<0.0001$ ). We conclude that estimation of CRP in CSF is a valuable, rapid, bedside diagnostic test for differentiating between pyogenic and viral meningitis with reasonably good sensitivity, specificity and positive predictive value. The absence of CRP in CSF rather than its presence is more important for the diagnosis of viral meningitis. Maximum prediction of pyogenic meningitis can be made if the CSF - CRP test is positive.

\section{What does this study Add to the existing knowledge?}

We recommend estimation of CRP in CSF of patients with meningitis when other parameters are non conclusive to diagnose the subtype of meningitis, however its routine testing needs further evaluation with bigger sample size, utilizing accurate and precise quantitative assay for measuring CRP levels in CSF.

\section{Author's Contribution}

Manoj Kumar M.D. - Conceived and Designed.

Chandra Shekhar Tiwari M.D.- Research designed, assessing the population, data collection, contribution in analysis and wrote the paper.

Nandita Prabhat D.M. (Neurology)- Data Collection and contribution in analysis.

Pooja Dhaon M.D. - Performed data analysis.

Dharmendra Uraiya M.D. - Critical revision of the article and final approval of the version to be published. 


\section{Reference}

01. Greenlee JE, Carroll KC. Infections of the Central Nervous System, 3rd edition. Scheld Lippincott Williams \& Wilkins, Philadelphia. 2004;5 p. [Crossref][PubMed][Google Scholar]

02. Tunkel AR. Principles and Practice of Infectious Diseases, 7th ed. Vol 1. Churchill Livingstone Elsevier, Philadelphia. 2010;1183 p [Crossref] [PubMed][Google Scholar]

03. Conly JM, Ronald AR. Cerebrospinal fluid as a diagnostic body fluid. Am J Med. 1983 Jul 28;75(1B)102-8. doi: 10.1016/00029343(83)90080-3 [Crossref][PubMed][Google Scholar]

04. Durand ML, Calderwood SB, Weber DJ, Miller SI, Southwick FS, Caviness VS Jr, Swartz MN. Acute bacterial meningitis in adults- A review of 493 episodes. N Engl J Med. 1993 Jan 7;328(1)21-8. doi: 10.1056/NEJM199301073280104 [Crossref] [PubMed][Google Scholar]

05. Vaidya AK, Wagle NM, Merchant SM. Use of CSF $C$-reactive protein in differentiating bacterial and non-bacterial meningitis. J Postgrad Med. 1987 Apr;33(2)58-60.

[Crossref][PubMed][Google Scholar]

06. Malla KK, Malla T, Rao KS, Basnet S, Shah R. Is Cerebrospinal Fluid C-reactive Protein a Better Tool than Blood C-reactive Protein in Laboratory Diagnosis of Meningitis in Children?. Sultan Qaboos Univ Med J. 2013 Feb;13(1)93-9. doi: 10.12816/0003201 [Crossref][PubMed][Google Scholar]

07. Sirijaichingkul S, Tiamkao S, Sawanyawisuth K, Chotmongkol V. C reactive protein for differentiating bacterial from aseptic meningitis in Thai patients. J Med Assoc Thai. 2005 Sep;88(9)1251-6. [Crossref] [PubMed][Google Scholar]

08. De Beer FC, Kirsten GF, Gie RP, Beyers N, Strachan AF. Value of $C$ reactive protein measurement in tuberculous, bacterial, and viral meningitis. Arch Dis Child. 1984 Jul;59(7)653-6. doi: 10.1136/adc.59.7.653 [Crossref][PubMed] [Google Scholar]

09. Sirijaichingkul S, Tiamkao S, Sawanyawisuth K, Chotmongkol V. C reactive protein for differentiating bacterial from aseptic meningitis in Thai patients. J Med Assoc Thai. 2005 Sep;88(9)1251-6. [Crossref] [PubMed][Google Scholar]
10. Vaishnavi C, Dhand UK, Dhand R, Agnihotri N, Ganguly NK. C-reactive proteins, immunoglobulin profile and mycobacterial antigens in cerebrospinal fluid of patients with pyogenic and tuberculous meningitis. J Hyg Epidemiol Microbiol Immunol. 1992;36(3)317-25. [Crossref][PubMed][Google Scholar]

11. Hemvani N, D S Chitnis, SP Joshi. "C-Reactive Proteins in Cerebrospinal Fluid and its role in Differentiation of Meningitis". Indian Journal of Medical Microbiology. 19;1(2001)26-29. [Crossref] [PubMed][Google Scholar]

12. Gerdes LU, Jørgensen PE, Nexø E, Wang P. Creactive protein and bacterial meningitis- a metaanalysis. Scand J Clin Lab Invest. 1998 Aug;58(5)383-93. doi: 10.1080/00365519850186364 [Crossref][PubMed] [Google Scholar]

13. Hansson LO, Axelsson G, Linné T, Aurelius $E$, Lindquist $L$. Serum C-reactive protein in the differential diagnosis of acute meningitis. Scand J Infect Dis. 1993;25(5)625-30. doi: 10.3109/00365549309008552 [Crossref][PubMed] [Google Scholar]

14. Prasad PL, Nair M, Kalghatgi AT. Childhood Bacterial Meningitis and Usefulness of C-reactive Protein. Med J Armed Forces India. 2005 Jan;61(1)13-5. doi: 10.1016/S03771237(05)80110-8 [Crossref][PubMed][Google Scholar]

15. Vaidya AK, Wagle NM, Merchant SM. Use of CSF $\mathrm{C}$-reactive protein in differentiating bacterial and non-bacterial meningitis. J Postgrad Med. 1987 Apr;33(2)58-60.

[Crossref][PubMed][Google Scholar]

16. Sutinen J, Sombrero L, Paladin FJ, Julkunen I, Leinikki $P$, Hernandez $E$, et al. Etiology of central nervous system infections in the Philippines and the role of serum C-reactive protein in excluding acute bacterial meningitis. Int J Infect Dis. 1998-1999 Winter;3(2)88-93. doi: 10.1016/s12019712(99)90015-2 [Crossref][PubMed][Google Scholar] 